\title{
EFFECT OF HEAT STRESS ON AGRICULTURAL FIELD WORKERS SAFETY
}

\author{
HAMED, A. R. ${ }^{1}$, M. E. EGELA ${ }^{1}$, SAHAR E. MOSA ${ }^{1}$, \\ Y. A. SHAHATA ${ }^{2}$, HIBA K. ALLAM ${ }^{2}$ and FATEN E. YOUNIS ${ }^{2}$ \\ 1. Agric. Eng. Research Institute (AEnRI), Dokki, Giza, Egypt. \\ 2. Assistant professor, Faculty of Médicine, Menofiya University.
}

(Manuscript received 21 October 2018)

\begin{abstract}

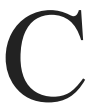
limate's change is one of the most important threats facing the world. That is because it causes a high ambient temperature. (UNEP, 2010). According to the report of the World Meteorological Organization (WMO, 2015), the period 20112015 recorded the highest temperatures and was affected by Climate's change. Agriculture sector is strongly influenced by climatic conditions. A majority of works in agriculture are still performed outdoors under several weather conditions. High temperature, intensive insolation and elevated air humidity providing a dangerous work conditions. These weather conditions can lead to overheating (heat stress) and dehydration of the agricultural field workers. An index assessing heat stress in human beings, namely: Wet Bulb Globe Temperature (WBGT) was used in this study. This study presents the effect of heat stress from the point of view of agricultural field worker occupational health safety. Comparison of the three agricultural working conditions reveals significantly more severe heat stress in wheat threshing, rice transplanting and cotton harvesting, in terms of both the frequency of heat-stress episodes and the number of hours associated with heat stress. The WBGT maximum values during the time from 11 am up to $4 \mathrm{pm}$ for wheat threshing, rice transplanting and cotton harvesting operations were $34.2{ }^{\circ} \mathrm{C}$ at $2 \mathrm{pm}, 31.6{ }^{\circ} \mathrm{C}$ at $1 \mathrm{pm}$ and $30.8^{\circ} \mathrm{C}$ at $1: 30 \mathrm{pm}$ respectively. While the WBGT minimum values were $31.7^{\circ} \mathrm{C}$ at $4 \mathrm{pm}, 28.4^{\circ} \mathrm{C}$ at $11 \mathrm{am}$, and $28.5^{\circ} \mathrm{C}$ at $4 \mathrm{pm}$ respectively. The three presented work conditions are affirmed that a dangerous situation for agriculture field workers is stand. The values of the environmental parameters and its relation with heat stress during the day work hours under the previous field operations cleared that the heat stress has direct proportion with humidex and reversible proportion with air velocity and relative humidity. The agriculture field workers have exposure to hazard levels of heat stress resulting in high levels of body temperature. It is recommended to establish a sunshade for wheat thresher to provide a shade working area.
\end{abstract}

Keywords: heat stress, field workers, safety, WBGT, humidex.

\section{INTRODUCTION}

The global average air temperature shows a warming of about $0.85^{\circ} \mathrm{C}$ over the period of 1880 to 2012 according to the Intergovernmental Panel on Climate Change (IPCC, 2013). A further warming of about $1^{\circ} \mathrm{C}$ per decade would be expected with the continued emission of greenhouse. Farming operations carried out by farmers 
are normally at high risk of heat stress, as they work under high pressure, perform extended hours of work in high of heat and humidity, suffer dehydration and often do not have sufficient knowledge on the prevention of heat exposed (Schenker, 2011). The health risks here are reflecting an increase in body temperature and/or excessive sweat loss and dehydration, and these are in fact very well- known consequences of exposure to heat (Parsons 2003). Agricultural field workers spend many hours under intense sunlight in almost all the farming operations. Thus, they engage themselves in heavy work under a hot environment that may subsequently result in heat stress (Yisa, 2005). In addition, heat stress may lead to reduction in task productivity which normally results in their lowered manual dexterity (Parsons, 2013). Agricultural field workers exposed to high temperature resulted in heat stress related symptoms such as; heat cramp, exhaustion, syncope and even heat stroke (Sadiq, 2016). Occupational heat stress is a well-known hazard in outdoor workplaces exposed to strong sunlight and elevated environmental temperatures, such as those associated with work in agriculture, forestry, quarrying, roadbuilding and construction (Nag and Nag 2009). Several indicators of occupational heat exposure incorporating physical properties of the ambient environment have been developed.

The indices used most frequently are Wet Bulb Globe Temperature (WBGT), humidity index (Humidex), Effective Temperature (ET) and Corrected Effective Temperature (CET) (Epstein \& Moran 2006), as well as the recently-developed Universal Thermal Climate Index (UTCI) (Błażejczyk et al. 2014). The WBGT is the most heat stress index widely-used (ISO, 2017). During the warm part of the year, the overall environmental conditions as regards heat can assume levels that give rise to occupational health risks and can reduce worker productivity in any outdoor workplaces (Kjellstrom et al. 2009). There are no official guidelines and the majority of advisers do not guide farmers in relation to implementing solutions to mitigate heat stress (Tjasa et al. 2017). Outdoor agriculture is a particularly high-risk industry with an occupational mortality rate 20 times higher than all industries combined in the USA (CDC 2008). There are several reasons for this, e.g. incentives to increase hourly work output, a lack of shade structures and breaks during the working day, and inadequate water availability and intake (Leibman \& Augustave 2010). Heat fatigue, heat cramps, heat exhaustion, heat syncope and heat stroke are heat-related diseases and they are results from various degrees of thermoregulatory system failure of the body (Heat-waves: risks and responses 2004). The incidence of heat-related disorders increases with higher ambient temperatures (Jason, 2006). Internationally, different authors and Governmental institutions have assessed heat stress effects on workers and also have described different methods to measure its 
negative impact on productivity as well as mechanisms to control and diminish these effects (Rodahl, 2003 and NIOSH, 2009). In an epidemiological research which done in Japan revealed that death from heat stroke in the occupational field occurred at $34^{\circ} \mathrm{C}$ dry bulb temperature when the relative humidity was less than $40 \%$. It occurred at around $28-30^{\circ} \mathrm{C}$ at dry bulb temperature when the relative humidity was more than $65 \%$ (Nakai, 1996). Heat stress is the sum of all the internal and external heat factors which cause the body to become fatigued and distressed. In extremely hot environments there is a significant decrease in productivity and a high rate of accidents as well as the risk of workers suffering heat disorders. Internal factors that determine the level of heat stress on the body include body temperature, acclimatization, natural heat tolerance and metabolic heat generated by the workload. External factors include ambient air temperature, radiant heat, air velocity and humidity. Heat stress in Egypt has not been given the importance it deserves, especially in relation to carrying out work in outdoor settings, such as agricultural activities. This emphasizes the need for increased information and implementation of feasible solutions to mitigate the negative impact of the heat stress on field workers in the agricultural sector. The objective of this study is to assess the heat stress risk among the agricultural field workers during the hot period of the year and evaluating the physiological responses of exposed workers.

\section{MATERIAL AND METHODS}

The present study aims of assessing the risk of heat stress caused by extreme heat exposure among the agricultural field workers working outdoor during the hot period of the year (April-October) under three field operations (wheat threshing, rice transplanting and cotton harvesting). The Egyptian Environmental Law (EEL) number 4/1994 modified issue in 2012 works according the heat stress measurements proposed by the American Conference of Government Industrial Hygienists (ACGIH, 2008), and follow WBGT index value of $28^{\circ} \mathrm{C}$ as the "permissible heat exposure threshold limit". Under the recent study, the calculations of the heat-stress measures were made at every half hour under a typical field work conditions for intensive field operations.

To evaluate the heat-stress risk in occupational health assessment among agricultural field workers, the WBGT index was used. The WBGT index (ISO 7243, 2017) involves weighted values of the natural wet-bulb temperature $\left(T_{n w},{ }^{\circ} \mathrm{C}\right)$, globe temperature $\left(\mathrm{T}_{\text {globe }},{ }^{\circ} \mathrm{C}\right)$ and dry-bulb temperature $\left(\mathrm{Ta}^{\circ}{ }^{\circ} \mathrm{C}\right)$ formulated as:

$$
\text { WBGT }=0.7 \cdot \mathrm{T}_{\mathrm{nw}}+0.2 \cdot \mathrm{T}_{\text {globe }}+0.1 \cdot \mathrm{T}_{\mathrm{a}}
$$

Humidex combines from air temperature $\left(\mathrm{Ta},{ }^{\circ} \mathrm{C}\right)+$ air vapor pressure $\left(\mathrm{v}_{\mathrm{p}}, \mathrm{hPa}\right)$ into one number reflecting the perceived temperature (ISO 7243, 2017) formulated as: 


$$
\text { humidex }=T_{a}+0.5555\left(v_{p}-10\right)
$$

The $3 \mathrm{M}^{\mathrm{TM}}$ QUESTemp ${ }^{\mathrm{TM}}$ heat stress monitor Kit QT32 was used for measuring the WBGT index parameters (dry bulb temperature, globe temperature, heat index/humidex, relative humidity) as shown in Fig. (1).

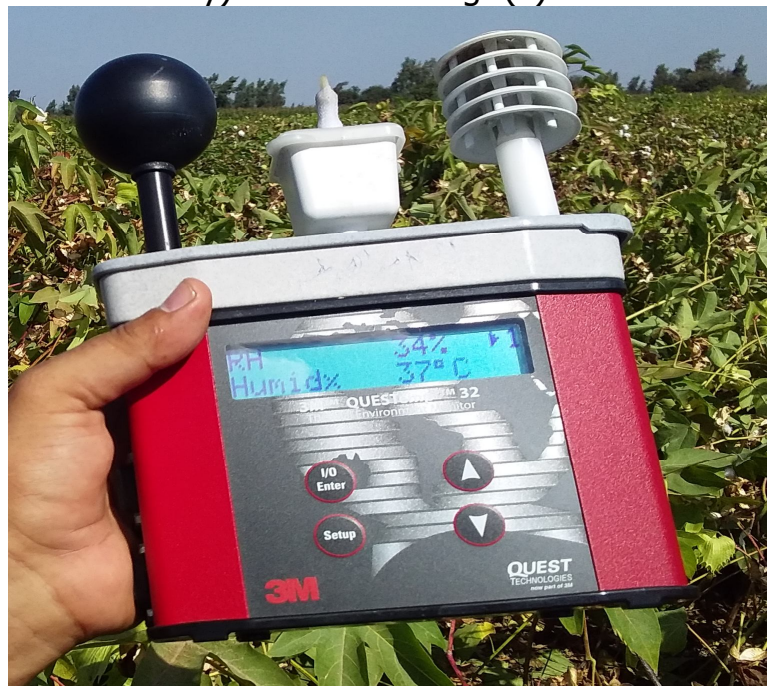

Fig. 1. The WBGT $3 M^{\mathrm{TM}} \mathrm{QUEST}$ emp ${ }^{\mathrm{TM}}$.

The stored data were compiled by a personal computer at the end of experiment for analyzing the treatments. Hygro-thermo-anemometer model 407412 was used for measuring the air velocity, air temperature and relative humidity under the work conditions. Table 1 presented the ACGIH screening criteria for the heat stress being based on WBGT workload and work/rest regimen and its threshold limit values.

Table 1. Threshold limit values of WBGT, (ISO 7243).

\begin{tabular}{|l|c|c|c|c|}
\hline \multicolumn{1}{|c|}{$\%$ Work } & \multicolumn{4}{c|}{ Workload } \\
\hline & Light & Moderate & Heavy & Very Heavy \\
\hline 75 to $100 \%$ (Continuous) & $31.0^{\circ} \mathrm{C}$ & $28.0^{\circ} \mathrm{C}$ & N/A & N/A \\
\hline 50 to $75 \%$ & $31.0^{\circ} \mathrm{C}$ & $29.0^{\circ} \mathrm{C}$ & $27.5^{\circ} \mathrm{C}$ & N/A \\
\hline 25 to $50 \%$ & $32.0^{\circ} \mathrm{C}$ & $30.0^{\circ} \mathrm{C}$ & $29.0^{\circ} \mathrm{C}$ & $28.0^{\circ} \mathrm{C}$ \\
\hline 0 to $25 \%$ & $32.5^{\circ} \mathrm{C}$ & $31.5^{\circ} \mathrm{C}$ & $30.5^{\circ} \mathrm{C}$ & $30.0^{\circ} \mathrm{C}$ \\
\hline
\end{tabular}

The global average air temperature shows a warming of about $0.85{ }^{\circ} \mathrm{C}$ on climate change a further warming would be expected with the continued emission of greenhouse according to IPCC (2013). Fig. 2 shows the mean monthly air temperature of the hot period for last five years 2013-2017 (CLAC, 2018) for Kalleen, Kafr ElSheikh Governorate where the study was conducted. The average daily value of ambient air temperature exceeds $40^{\circ} \mathrm{C}$ monitored in many days from June to September. 


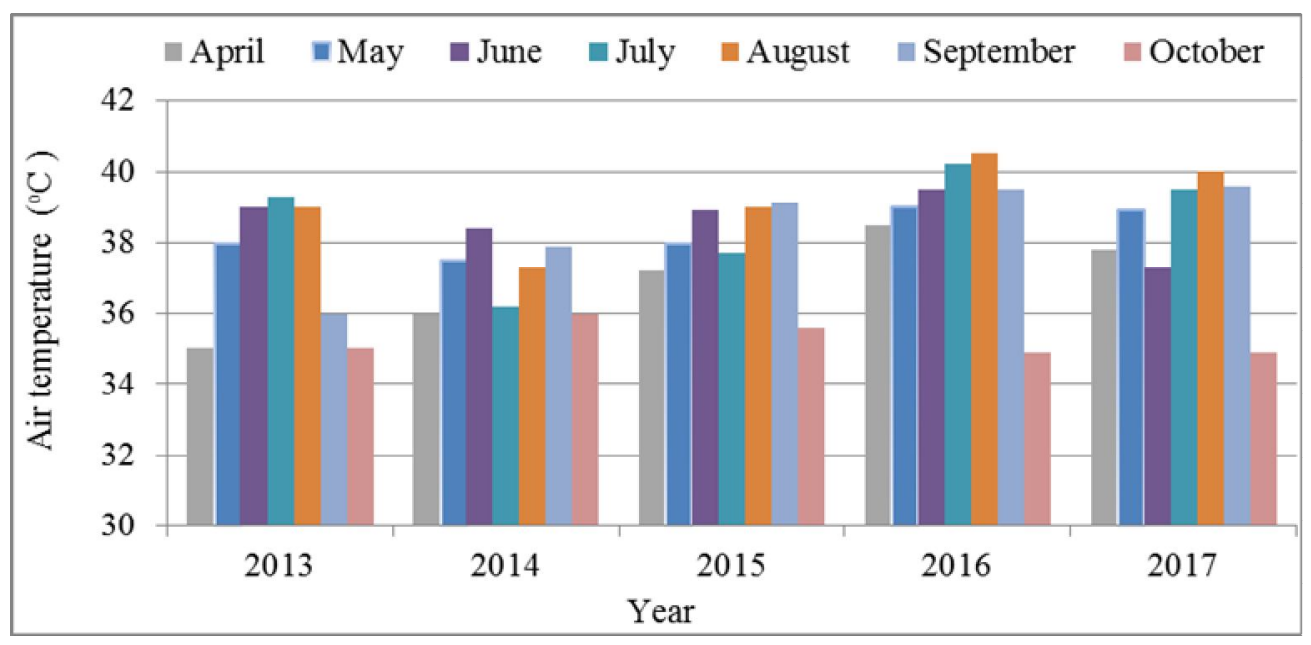

Fig. 2. Mean monthly air temperature of the last five years for Kaleen.

A total of twenty agricultural field workers were used for each field operation in this study. They were randomly selected among the agricultural field workers available. The physical characteristics of the selected agricultural field workers were measured. Height and weight were used to calculate a participant's body mass index (BMI) according to the World Health Organization (WHO, 2000). Farm workers characteristics under this study showed that the highest percentage of body mass index was (55\%) for overweight body followed by ideal body was (30\%) and for obesity body was (15\%). The three agricultural field workers were classified as; Less than 18 consider thin; $18-24$ is ideal; $25-29$ is overweight; $30-39$ is obesity and more than 40 are over obesity. The highest number of agricultural field workers was in both of the age group of (41-45) and (46-50) years with percentage of (25\%). The group of (51-55) years represented by (15\%), followed by the groups of (21-25), (36-30) and (31-35) years with percentage of (10\%). but the lowest number of field worker's was in the age group of (56-60) years with percentage of (5\%).

A measurements of systolic blood pressure (SBP), diastolic blood pressure (DSBP) were taken using automatic blood pressure monitor UA-651. The measured blood pressure was classified according to WHO (2003). Body temperature was taken using a thermometer and a balance for weigh. The measurements were carried out before and after each work shift to clarify the effect of heat stress on the worker. A completely randomized design of field layout design was taken. The subjects were taken as replications. The data were processed for frequencies procedure and analysis of variance using statistical package for social science, SPSS version 20 software and a probability value of $p \leq 0.05$ was considered to show a statistical significant difference among mean values (Snedecor and Cochran, 1989). 


\section{RESULTS}

\section{Heat stress WBGT under different field operation conditions}

Results in Fig. 3 showed that the maximum and the minimum values of WBGT are $34.2{ }^{\circ} \mathrm{C}$ at $2 \mathrm{pm}$ and $31.7^{\circ} \mathrm{C}$ at $4 \mathrm{pm}$ for wheat threshing operation respectively. The maximum and the minimum values of WBGT are $31.6^{\circ} \mathrm{C}$ at $1 \mathrm{pm}$ and $28.4^{\circ} \mathrm{C}$ at $11 \mathrm{am}$ for rice transplanting operation respectively. Then the maximum and the minimum values of WBGT are $30.8^{\circ} \mathrm{C}$ at $1: 30 \mathrm{pm}$ and $28.5^{\circ} \mathrm{C}$ at $4 \mathrm{pm}$ for cotton harvesting operation respectively. According the data presented in Table (1), it is cleared that the heat stress for the wheat threshing is out of the threshold limit, so under the heat stress categories there is extreme risk on the workers, it is impermissible to work in these circumstances. On the other hand for the rice transplanting and cotton harvesting the workers should work $50 \%$ and have rest of work $50 \%$ during the time.

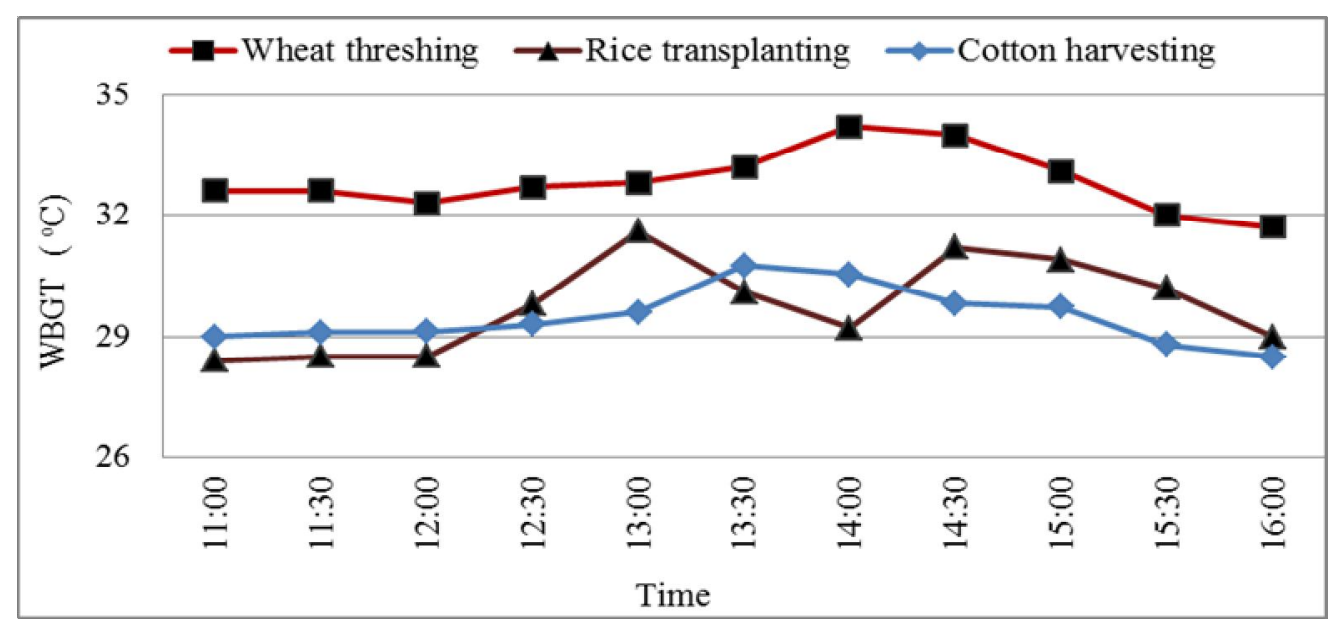

Fig. 3. Heat stress WBGT for the field operations

\section{Data analysis of ANOVA for heat stress under different field operations}

Table 2 and 3 present the results of the statistical analysis of ANOVA for the WBGT conducted of the three field operations (wheat threshing, rice transplanting and cotton harvesting). Data analysis showed that there was highly significant difference between the field operations WBGT $(F=49.15)$. it means that the treatment variation (values of WBGT) is bigger than experimental error and the c.v. is smaller than $10 \%$ which means that the values of experiment are reliable to apply. 
Table 2. Analysis of variance for the WBGT conducted of the three field operations.

\begin{tabular}{|c|c|c|c|c|c|c|c|c|}
\hline \multirow{2}{*}{ Heat stress of farm operations } & \multirow{2}{*}{ Mean } & \multirow{2}{*}{ S. D. } & \multirow{2}{*}{$\begin{array}{l}\text { C.V. } \\
\%\end{array}$} & \multirow{2}{*}{$\begin{array}{l}\text { Std. } \\
\text { Err. }\end{array}$} & \multicolumn{2}{|c|}{$\begin{array}{l}\text { 95\% Confidence } \\
\text { Interval for Mean }\end{array}$} & \multirow{2}{*}{$\mathrm{F}$} & \multirow{2}{*}{ Sig. } \\
\hline & & & & & $\begin{array}{l}\text { Lower } \\
\text { Bound }\end{array}$ & $\begin{array}{l}\text { Upper } \\
\text { Bound }\end{array}$ & & \\
\hline WBGT of wheat threshing, ${ }^{\circ} \mathrm{C}$ & 32.8 & \pm 0.76 & 2.30 & 0.22 & 32.34 & 33.35 & \multirow{3}{*}{49.15} & \multirow{3}{*}{0.00} \\
\hline WBGT of rice transplanting, ${ }^{\circ} \mathrm{C}$ & 29.7 & \pm 1.13 & 3.79 & 0.34 & 29.01 & 30.53 & & \\
\hline WBGT of cotton harvest, ${ }^{\circ} \mathrm{C}$ & 29.4 & \pm 0.70 & 2.38 & 0.21 & 29.00 & 29.94 & & \\
\hline
\end{tabular}

Table 3. Analysis of least significant difference for the WBGT conducted of the three field operations.

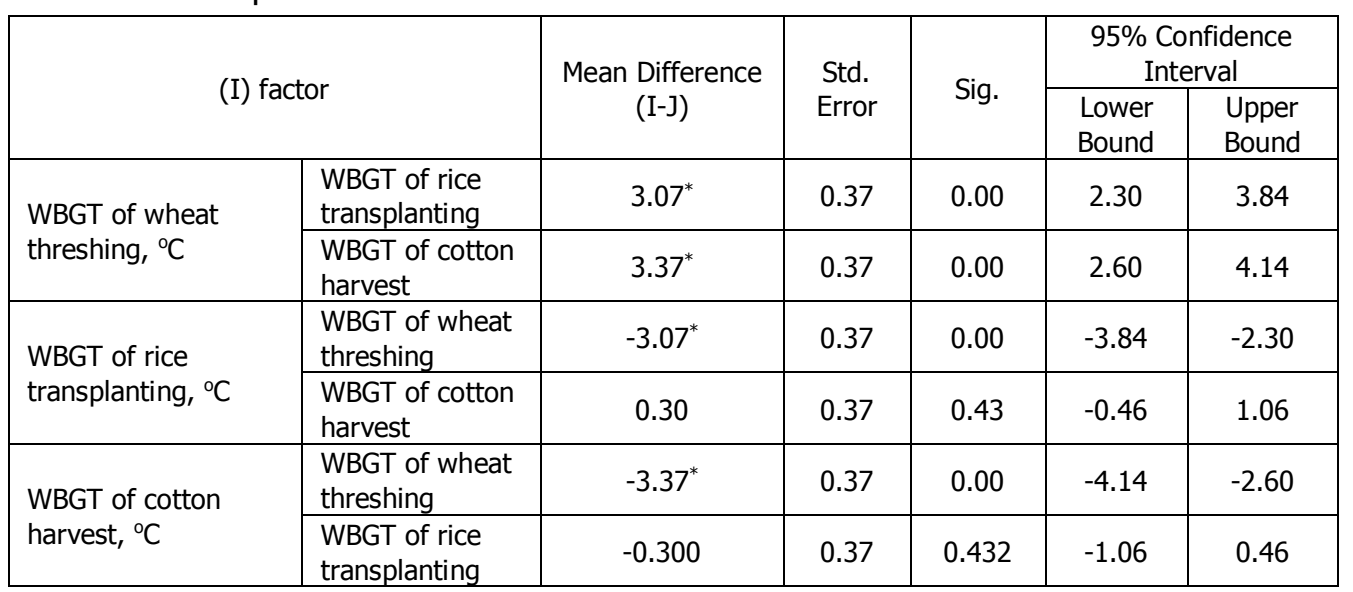

\section{Effect of environmental parameters of the heat stress under different field operations}

The environmental parameters measured under field operations including humidex, relative humidity, air velocity and WBGT of the work shift are demonstrated in Table 4. The results show that the mean values of the WBGT for wheat threshing operation was $32.8{ }^{\circ} \mathrm{C}$, resulting from the environmental parameters humidex $\left(40.7^{\circ} \mathrm{C}\right)$, relative humidity $(43 \%)$ and air velocity $(1.55 \mathrm{~m} / \mathrm{s})$. The mean values of the WBGT for rice transplanting operation was $29.7^{\circ} \mathrm{C}$, resulting from the environmental parameters humidex $\left(38^{\circ} \mathrm{C}\right)$, relative humidity $(43.2 \%)$ and air velocity $(1.6 \mathrm{~m} / \mathrm{s})$ and the mean values of the WBGT for cotton harvesting operation was $29.4{ }^{\circ} \mathrm{C}$, resulting from the environmental parameters humidex $\left(35^{\circ} \mathrm{C}\right)$, relative humidity $(35.5 \%)$ and air velocity $(2.2 \mathrm{~m} / \mathrm{s})$.

The values of the environmental parameters and its relation with heat stress during the day work hours under each field operation cleared that heat stress has direct proportion with humidex and reversible proportion with air velocity and relative humidity. On the other hand, the mean values of the environmental parameters and its relation with heat stress for the three seasons cleared that, the heat stress has direct proportion with humidex and relative humidity but reversible proportion with air velocity. 
Table 4. Environmental parameters of the WBGT for the three field operations.

\begin{tabular}{|c|c|c|c|c|c|c|}
\hline Farm operation & Time & $\begin{array}{c}\text { Humidex } \\
{ }^{\circ} \mathrm{C}\end{array}$ & $\begin{array}{c}\text { Humidity } \\
\%\end{array}$ & $\begin{array}{c}\text { Air velocity } \\
\mathrm{m} / \mathrm{s}\end{array}$ & $\begin{array}{l}\text { WBGT } \\
{ }^{\circ} \mathrm{C}\end{array}$ & $\begin{array}{c}\text { WBGT } \\
\text { SD }\end{array}$ \\
\hline \multirow{6}{*}{ 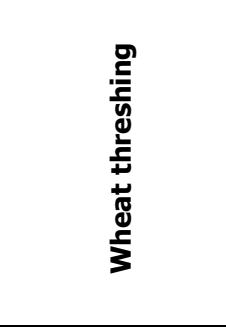 } & $11: 00$ & 40 & 43 & 0.9 & 32.6 & \pm 0.1 \\
\hline & $12: 00$ & 41 & 45 & 1.4 & 32.3 & \pm 0.15 \\
\hline & $13: 00$ & 42 & 42 & 0.5 & 32.8 & \pm 0.33 \\
\hline & $14: 00$ & 41 & 42 & 0.5 & 34.2 & \pm 0.78 \\
\hline & $15: 00$ & 39 & 44 & 2.9 & 33.1 & \pm 0.57 \\
\hline & $16: 00$ & 39 & 42 & 3.1 & 31.7 & \pm 0.46 \\
\hline Avg. & & 40.7 & 43 & 1.55 & 32.8 & \pm 0.40 \\
\hline \multirow{6}{*}{ 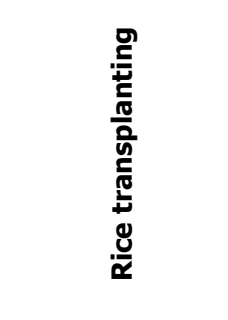 } & $11: 00$ & 37 & 46 & 0.9 & 28.4 & \pm 0.1 \\
\hline & $12: 00$ & 38 & 39 & 1.5 & 28.5 & \pm 0.1 \\
\hline & $13: 00$ & 41 & 43 & 0.5 & 31.6 & \pm 0.71 \\
\hline & $14: 00$ & 38 & 42 & 0.5 & 29.2 & \pm 0.28 \\
\hline & $15: 00$ & 38 & 46 & 3.1 & 30.9 & \pm 0.47 \\
\hline & $16: 00$ & 36 & 43 & 3.3 & 29 & \pm 0.42 \\
\hline Avg. & & 38 & 43.2 & 1.6 & 29.7 & \pm 0.35 \\
\hline \multirow{6}{*}{ 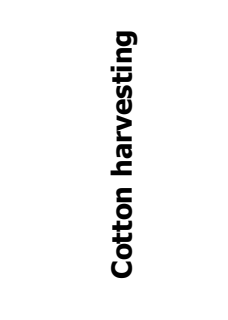 } & $11: 00$ & 34 & 40 & 3 & 29 & \pm 0.1 \\
\hline & $12: 00$ & 35 & 38 & 1.6 & 29.1 & \pm 0.1 \\
\hline & $13: 00$ & 36 & 37 & 1.7 & 29.6 & \pm 0.28 \\
\hline & $14: 00$ & 38 & 33 & 2.4 & 30.5 & \pm 0.68 \\
\hline & $15: 00$ & 35 & 30 & 2.6 & 29.7 & \pm 0.47 \\
\hline & $16: 00$ & 33 & 35 & 2 & 28.5 & \pm 0.4 \\
\hline Avg. & & 35 & 35.5 & 2.2 & 29.4 & \pm 0.34 \\
\hline
\end{tabular}

\section{Assessment of the heat stress on the human body temperature}

Experimental results as shown in Fig. 4 indicated that, the temporary body temperature of the field workers are increased due to exposure to heat stress exceed the criterion level WBGT value of $28^{\circ} \mathrm{C}$. For wheat threshing, rice transplanting and cotton harvesting farm operation workers, the body temperature of the workers values were $37.2,37.1$ and $37^{\circ} \mathrm{C}$ before work shift and $37.6,37.5$ and $37.3^{\circ} \mathrm{C}$ after the work shift respectively. This indicates that, the workers have exposure to hazard levels of heat stress resulting in high levels of body temperature. As a result under experimental conditions the workers must work less than 8 hour/day and have as least two times to rest during the day (Table (1)) in general, to ensure working in safe conditions corresponding to that, the workers' productivity will be less. 


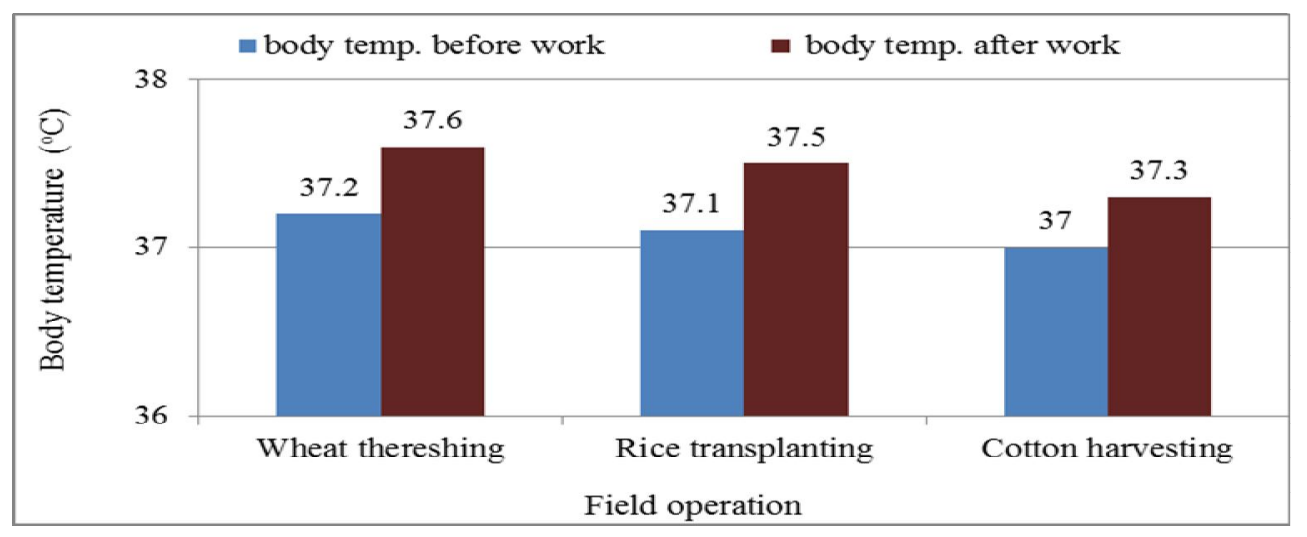

Fig. 4. Agricultural field workers body temperature before and after work.

\section{Interaction between heat stress exposure and blood pressure}

The interaction between heat stress exposure and blood pressure was carried out according the classification of blood pressure (WHO, 2003). The SBP and DBP of field workers asymptotic are increased due to exposure to heat stress exceed the criterion level $\left(28^{\circ} \mathrm{C}\right)$. For wheat threshing, rice transplanting and cotton harvesting farm operation workers, the SBP values were 133, 106 and $117(\mathrm{mmHg})$ before work shift and 155, 127 and $136(\mathrm{mmHg})$ after the work shift respectively. The workers DBP of wheat threshing, rice transplanting and cotton harvesting were 81, 79 and 76 $\mathrm{mmH}$ before the work shift and 98, 101 and $91 \mathrm{mmHg}$ after the work shift respectively. This indicates that, the workers have exposure to hazard levels of heat stress resulting in high levels of both the SBP and the DBP. As a result, the workers must work less than 8 hour/day and have as least two times to rest during the day, in general, to ensure working in safe conditions corresponding to that, the workers' productivity will be less. The majority of the workers SBP after work shift were stage one hypertension ( $45 \%)$ and also pre-hypertension (45 \%) followed by normal (10 $\%)$, and before work shift was normal (60\%), followed by pre-hypertension (40\%). The workers DBP after work shift were stage one hypertension (65\%), followed by pre-hypertension (25\%) and (10\%) for high blood pressure crisis and before work shift were normal (75\%) followed by pre-hypertension (15\%) and (10\%) for stage one hypertension. It concluded that there was association between heat stress exposure and blood pressure among the workers.

\section{DISCUSSIONS}

In this investigation, the measured WBGT index values exceeded threshold limit value $\left(28^{\circ} \mathrm{C}\right.$, considering workload, work- rest regimen) almost in all studied work environments including wheat threshing, rice transplanting and cotton harvesting, especially between 11: 00 am to 15: $00 \mathrm{pm}$ and in hot period. The condition was worst for the wheat threshing work environments. So that, the WBGT index had reached maximum value $\left(34.2^{\circ} \mathrm{C}\right)$. These values obtained in conditions in which, dry air temperatures and globe bulb temperatures more than $40^{\circ} \mathrm{C}$ experienced 
by the subjects (Table 4). In hot and humid environments, it can be seen that the WBGT index exceeded the recommended limit value. According to the fractional portions of each environmental parameter, which demonstrated in equation 1 , the relative humidity has the main role in heat stress of the environment in such situations. Evaluation results based on the WBGT index have been higher than the allowable limit, while the obtained results based upon physiological responses, especially in cases of oral temperatures, have been lower than standard references value $\left(37^{\circ} \mathrm{C}\right.$ for oral temperature. The most important parameters, which can be change WBGT index values are relative humidity and resultant natural wet bulb temperature. Heat stress affects human health and productivity whenever the body temperature rises above $38^{\circ} \mathrm{C}$. This is caused as a result of exposure to high temperature and humidity, intense physical activity and poor medical condition. The health impact of heat stress ranges from heat cramps, syncope, exhaustion and heat stroke

\section{CONCLUSION}

Results of the research presented clarifying that the agricultural field workers doing outdoor work being faced stressful climatic conditions. Then climate characterized here is with a large number of heat-stress hours. Very important feature of the hot period of the year from May to September that can lead to a great risk in the cases of agricultural field workers working outdoors. Similarly, the evaluation of heat stress using WBGT in such environments (hot and humid condition), may face us with inaccurate judgment about the real environment. On the other hand, the workers who work under heat condition at outside environment have often heavy jobs and without any awareness and knowledge on heat stress. Therefore, evaluation of heat exposures and exposed workers using both the heat stress and heat strain indices strongly suggested. Beside this, raising workers awareness on heat stress, health care provision and providing heat preventive indicators at workplace are necessary for relief of health risk in hot and humid environments. There for the agricultural field workers must pay attention to protect themselves against the risk of overheating of the body and dehydration by drinking enough water, as well as cooling their body down periodically through time spent in the shade and wearing the suitable clothes (light cotton clothes and light colored ones, sun hat with wide brim.

\section{RECOMMENDATIONS}

1- Use of personal protective tools like; wear breathable, light-weight, light-colored clothing and sun hat with wide prime to reduce the heat stress harmful impact.

2- Organize work schedules to exchange work activities so that no one of workers is exposed to the heat stress for more than permissible hours in one day.

3- Establish a sunshade for wheat thresher to provide a shade working area. 
4- Perform farther studies of heat stress in various agricultural work environments to increase the workers safety and work productivity.

\section{REFERENCES}

1. ACGIH- American Conference of Governmental Industrial Hygienist. 2008. Threshold Limit Values for Chemical Substances, Physical Agents and Biological Exposure Indices, Cinnati, $\mathrm{OH}$.

2. Błazejczyk, K.; J. Baranowski and A. Błazejczyk. 2014. Heat stress and occupational health and safety - spatial and temporal differentiation. Miscellanea Geographica - Regional Studies on Development, vol. 18 (1): 61-67.

3. Centers for Disease Control and Prevention, CDC. 2008. Heat-Related Deaths among Crop Workers- United States, 1992-2006. MMWR Weekly. 57 (24): 649653.

4. Epstein Y., Moran D.S. 2006. Thermal comfort and heat stress indices. Industrial Health. 44: 388-398.

5. Heat-waves: risks and responses. 2004. Health and Global Environmental Change, Geneva: Health and Global Environmental Change, SERIES, 2, Who. Assessment of occupational heat stress risk among agriculture workers in Poland and Bulgaria 71.

6. Central Laboratory for Agricultural Climate, CLAC (2013-2017). Data collected and computed. Ministry of Agriculture and Land Reclamation. Egypt.

7. Intergovernmental Panel on Climate Change, IPCC. 2013. Summary for Policymakers. In: Climate Change: The Physical Science Basis. Contribution of Working Group I to the Fifth Assessment Report of the IPCC. Cambridge University Press, Cambridge, United Kingdom and New York, NY, USA.

8. ISO 7243 (2017). Ergonomics of the thermal environment- assessment of heat stress using the WBGT (wet bulb globe temperature) index.

9. Jason Hoppe, D. O. 2006. Heat exhaustion and heatstroke. University of New York Downstate Medical Centre, Kings County Hospital. March. Emergency medicine. Available from: www.emedicine.com/emerg/topic236.

10. Kjellstrom, T.; I. Holmér and B. Lemke. 2009. Workplace heat stress, health and productivity- an increasing challenge for low- and middle-income countries during climate change. Global Health Action, 2.

11. Leibman, A. K. and W. Augustave. 2010. Agricultural Health and Safety: Incorporating the Worker Perspective. Journal of Agromedicine. 15 (3): 192-199.

12. Nag, P. K. and A. Nag. 2009. Vulnerability to heat stress: Scenario in Western India. Ahmedabad, National Institute of Occupational Health. http://searo.who.int/ india/topics/ occupational health/ Occupational Health Vulnerability to heat stress scenario of western India. 
13. Nakai, S.; K. Shinzato and T. Morimoto. 1996. Epidemiological analysis of heat disorders in Japan. An analysis of gleaned cases from newspaper report between 1990 and 1994. Jpn J Biometeorol; 33: 7-17.

14. National Institute of Occupational Safety and Health, NIOSH. 2009. Working in hot environments. Cincinnati, OH: U.S. Department of Health and Human Services, Public Health Service, Centers for Disease Control, National Institute for Occupational Safety and Health, DHHS (NIOSH) Publication No. 86-112. http://www.cdc.gov/niosh/hotenvt.

15. Parsons, K. 2003. Human thermal environments. The effects of hot, moderate and cold temperatures on human health, comfort and performance. $2^{\text {nd }}$. Ed. London: Taylor and Francis.

16. Parsons, K. 2013. Human Thermal Environments: The Effects of Hot, Moderate and Cold Environment on Human Health, Comfort and Performance. $3^{\text {rd }}$. Ed. CRC Press.

17. United Nation Environment Program. 2010. The Emission Gap Report. Retrieved from www.unep.org/publications/ebooks.

18. Rodahl, K. 2003. Occupational health conditions in extreme environments. Ann. Occup. Hyg. 47: 241-52.

19. Sadiq, L. S. 2016. Assessing the Impact of Heat on Health and Productivity among Nigerian. Asia Pacific Environmental and Occupational Health. 2 (3): 6-9.

20. Schenker, M. 2011. Occupational Heat-related Illness Among Agricultural Workers, in Climate Change and Occupational Health Expert Meeting, Lund University, Sweden: Lund, Sweden.

21. Snedecor, G. W. and W. G. Cochran. 1989. Statistical methods. Oxford \& J.BH Publishing com. $8^{\text {th }}$. Ed. 217-252.

22. Tjasa, P. Z.; L. K. Crepinsek; J. Bogata; and L. NYBO. 2017. Comprehension of climatic and occupational heat stress amongst agricultural advisers and workers in Slovenia. Acta Agriculture Slovenia. 109 (3): 545-554.

23. World Health Organization, WHO. 2000. Obesity: preventing and managing the global epidemic: report of a WHO consultation. WHO Technical Report Series, 894 (i-xii). 1-253.

24. World Health Organization, WHO. 2003. Statement of management on hypertension. Journal of hypertension. 21 (11): 1-15.

25. World Meteorological Organization, WMO. 2015. Report on Climate Change. www.wmo.int/wmo.

26. Yisa G.M. 2005. Ergonomics in a small scale grain mills in Nigeria, African Newsletter on Occupational Health and Safety, 15. 


\section{تأثير الاجهاد الحراري على سلامة عمال الحقل الزراعيين}

\section{أحمد رجب حامد1، محسن إبر اهيم عجيله1 ، سحر السيد احمد1 ، ياسر عطا شحاته 2 ، هبة خضرى علام2 و فاتن عز العرب يونس 2 \\ 1. معرد بحوث الهنسة الزراعية ، مركز البحوث الزراعية ، وزارة الزراعة . \\ 2. قسم الصحة العامة - كلية الطب - جامعة المنوفية .}

التغير المناخي أحد اهم المخاطر التي نو اجه العالم وذلك لأنه بسبب ارتفاع درجة حرارة البيئة المحيطة (UNEP, 2010). وبناء على تقرير المنظمة العالمية للأرصاد الجوية (WMO, 2015)

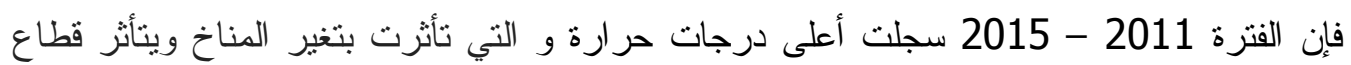
الزر اعة بشدة بالظروف المناخية وحيث تز ال غالبية العمليات الزر اعية تجري في ظل ظروف جورية

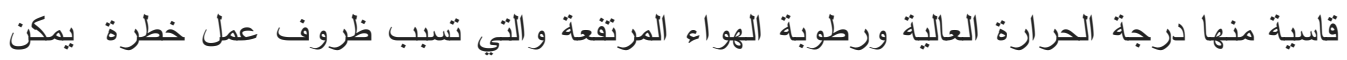

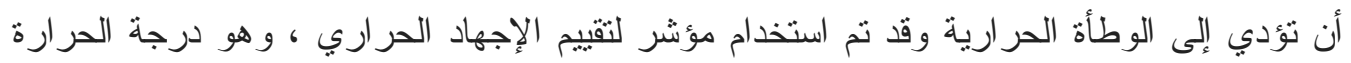

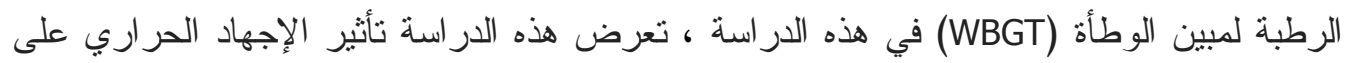

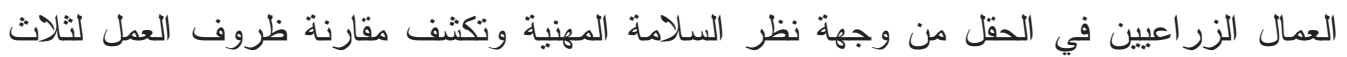

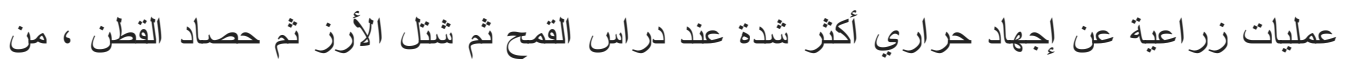

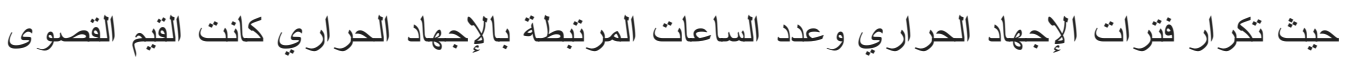

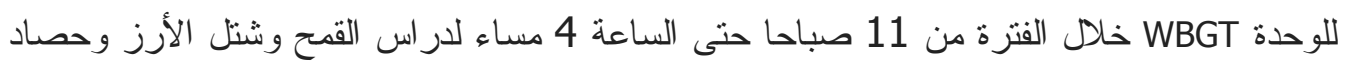

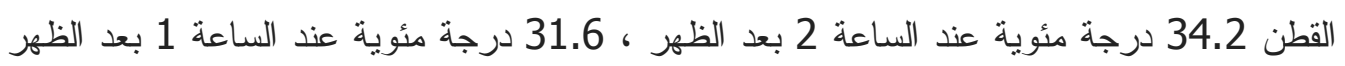

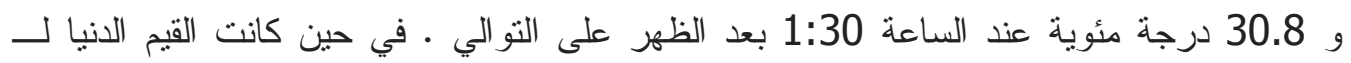

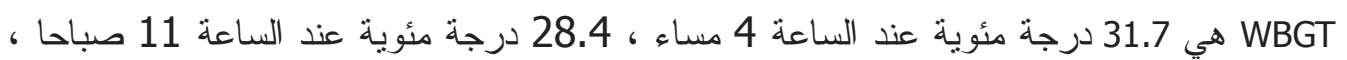

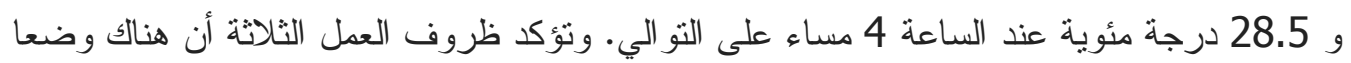
خطير ا للعاملين في الحقل الزر اعي. إن قيم المؤشرات البيئية وعلاقتها بالإجهاد الحراريه اري خلاءل

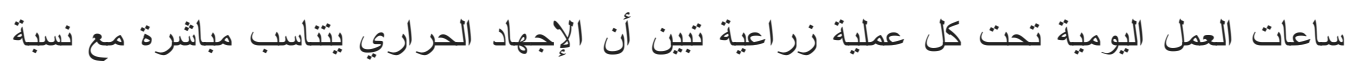

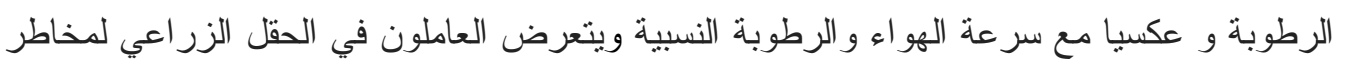
مستويات الإجهاد الحراري مما يؤدي إلى ارتفاع مستويات حرارة الجسم أعلى من المعدل المدل الطبيعي لحيز العمل ويوصى بعمل مظلة على آلة در اس القمح لتوفير بيئة عمل آمنة . 
